\title{
A Morpho-phonemic Analysis on Sasak Affixation
}

Wahyu Kamil Syarifaturrahman ${ }^{1}$, Sutarman ${ }^{* 2} \&$ Zainudin Abdussamad ${ }^{3}$

${ }^{123}$ Fakultas Sosial dan Humaniora, Universitas Bumigora, Indonesia

Corresponding Author: Sutarman, E-mail: sutarman@universitasbumigora.ac.id

\section{ARTICLE INFORMATION}

Received: November 17, 2020

Accepted: January 02, 2021

Volume: 4

Issue: 1

DOI: 10.32996/ijllt.2021.4.1.13

\section{KEYWORDS}

Morpho-phonemic, Sasak,

Affixation, Ngeno-Ngene dialect

\section{ABSTRACT}

The current study analyses the morpho-phonemic in Sasak affixation especially in Ngeno-Ngene dialect. This study is a qualitative research in nature. The data were collected via field linguistic method using three techniques of data collection: observation, interview, and note-taking. The study used a qualitative research method to describe all morphophonemic process of affixation in Ngeno-Ngene dialect of Sasak language. The results of the study revealed that there are two affixes that undergo morphophonemic process, namely, prefix be-, pe-, ng-, t-, me- and simulfix ke-an. Prefix be- can cause epenthesis (additional $r$ ), prefix pe- causes epenthesis (additional $\mathrm{n}$ and $\mathrm{mi}$ ) and assimilation $(\mathrm{k} \cdot \mathrm{n})$, prefix $\mathrm{ng}$ - causes assimilation $(k \cdot \eta)$, prefix $t$ - causes epenthesis (additional e) and prefix me- causes assimilation $(p \cdot m)$. The simulfix ke-an in this dialect causes epenthesis in which there will be lexical addition ' $r, m, n$ ' when the simulfix ke-an is used.

\section{Introduction}

Affixation is an integral part of a language that has been discussed widely in most of languages in the world including Sasak language. Sasak language is a local language spoken in Lombok, a part of West Nusa Tenggara province in Indonesia. Sasak language involves in a Western Malayo- Polynesian language which is closely related to Samawa and Balinese and sub-groups as a member of the Western - Malayo Polynesian ranch of Austronesian (Austin, 2004). It has been claimed to have six local dialects- Menu-Meni dialect, Ngeno-Ngene dialect, Nggeto-Nggete dialect, Meriaq-Meriqu dialect, Kuto-Kute dialect, and MenoMene dialect (Mahyun, 2006).

Some studies on affixation have been conducted in particular dialects of Sasak language. A study on Menu-Meni dialect has been conducted by Sutarman (2017) entitled "Derivational and Inflectional affixation in Menu-Meni dialect of Sasak language". It found that Menu-Meni dialect has three affixes- prefix, suffix and confix. Fikri (2017) has conducted a research in Ngeno-Ngene dialect about verbal inflection and derivational process of Sasak language. Another research on affixation has also been conducted by Sukri (2015) under the title " $[M-N]$ Derivational and inflectional affixes in Sasak language on Kuto-Kute dialect'. The articles above show that affixation has been explored intensively. This article, however, seeks to study another side of affixation particularly on the morpho-phonemic analysis.

A morpho-phonemic approach on the affixation in Sasak language has not been explored yet because it studies an interaction between morphology and phonology in affixation. The interaction between morphology and phonology on affixation may result in the vowel changes as in knife and knives in English. This study is conducted in Ngeno-Ngene dialect of Sasak language which is mostly spoken in east and west Lombok. The current study has two fold purposes; 1 ) to investigate types of Sasak affixation that undergo morpho-phonemic changes, and 2) to elaborate the phonemic changes on the affixation.

\section{Literature Review}

\subsection{Affixation}

An affix is defined as a bound morpheme that can only occur if attached to a word or stem (Hanafi, 2006). Akmajian (1976) says that affixes relate to the prefixes when they are attached to the beginning of another morpheme as in re-write and re-think and as suffixes when they are attached to the end of another word as in modern-ize, equal-ize and standard-ize. Another definition

K C AL-KINDI CENTER R D FOR RESEARCH AND R D DEVELOPMENT Your gateway to world-class research

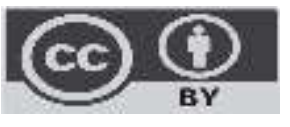

Published by Al-Kindi Center for Research and Development. Copyright (c) the author(s). This open access article is distributed under a Creative Commons Attribution (CC-BY) 4.0 license 
comes from Ramlan (1985) who states that affix is a unit of bounbd grammatical that is an element of a word, it is neither a word nor a base word, and it has an ability to attach at other units to form word or a new base word.

Affix is divided into derivational and inflectional one. Derivational affixes can change the word class and its meaning. a word can derive from one of the three-word classes such as verb, adjective, noun, and return another. See examples below

Table 1. Derivational affixes

\begin{tabular}{|l|l|l|}
\hline Verb & Noun & Adjective \\
\hline Play & player & Playful \\
\hline Teach & Teacher & Teachable \\
\hline Love & Lover & Lovable \\
\hline
\end{tabular}

However, some negative affixes cannot change the word category although they can create nouns, adjective and verbs with the opposite meaning. For instance, negative prefix un- and dis- can be used to produce noun, adjective, or verb with opposite meaning. Consider the following negative prefixes

$\begin{array}{ll}\text { Belief } & \rightarrow \text { unbelief } \\ \text { Interesting } & \rightarrow \text { uninteresting } \\ \text { Interested } & \rightarrow \text { uninterested } \\ \text { Clear } & \rightarrow \text { unclear } \\ \text { Understand } & \rightarrow \text { misunderstand } \\ \text { Legal } & \rightarrow \text { illegal }\end{array}$

Fromkin (1996) explains that there are some morphemes that add new meanings to an existing word which is called derivational morpheme. It causes a change in grammatical class of the word as in the followings;

$\begin{array}{llll}\text { Desire (V) } & + \text { able } & =\text { desirable } & \text { (Adj) } \\ \text { Adore (V) } & + \text { able } & =\text { adorable } & \text { (Adj) } \\ \text { Health (N) } & + \text { ful } & =\text { healthful } & \text { (Adj) } \\ \text { Beauty (N) } & + \text { ful } & =\text { beautiful } & \text { (Adj) } \\ \text { Sing (N) + er } & =\operatorname{singer}(\text { N) } & \\ \text { Quiet (Adv) } & + \text { ly } & =\text { quietly } & \text { (Adv) }\end{array}$

Contrastively, some other derivational morphemes cannot change the grammatical class of the word as in examples below

$$
\begin{array}{ll}
\text { a }+ \text { moral } & =\text { amoral (Adj) } \\
\text { super }+ \text { human } & =\text { superhuman }(\mathrm{N}) \\
\text { re }+ \text { print } & =\operatorname{reprint}(\mathrm{V}) \\
\text { green }+ \text { ish } & =\text { greenish (adj) } \\
\text { music }+ \text { an } & =\text { musician }(\mathrm{N})
\end{array}
$$

On the other hand, inflectional morphemes do not cause any change on the syntactic category of a word. For instance, the change of verb which is caused by the tense does not change the verb category as in the followings

$$
\begin{aligned}
& \text { I study at school } \\
& \text { He studies at school } \\
& \text { He studied at school } \\
& \text { He has studied at school } \\
& \text { He is studying at school }
\end{aligned}
$$

The word "study" above undergoes inflectional suffixes which do not change the category of word. Thus, Yule (2014) states that the inflection does not change create new word category but show the grammatical function. 


\subsection{Morphological process}

Katamba (2003) says that morphological process is the process in which the language speaker combines one morpheme with another in to create a word. Hockett (1958) adds that morphology includes the stock or segmental morpheme and the ways in which words are built out of them. the morphological process seen from the definition includes the affixation, modification and reduplication. There are two types of morphological process, namely, affixation and non -affixation (Nurhayati, 2015; Sutarman, 2020)

A. Affixation : internal change

Suppletion : complete change of form as in the examples below

Go + ed $\rightarrow$ went

Good + er $\rightarrow$ better

Good + est $\rightarrow$ best

A core vowel change as in examples below

Foot + es $\rightarrow$ feet

Tooth + es $\rightarrow$ teeth

Zero modification : there is no change as in the followings

Put + ed $\rightarrow$ put

Deer + es $\rightarrow$ deer

b. Non affixation

There are some morphological processes include in non affixation such as compounding, blending, borrowing, coinage, clipping, and backformation.

Compounding is to combine two words which yield new meaning as in blackboard. The word ' blackboard' derive from two words 'black' and 'board'. After combination, it has new meaning which relates to any board which has black color.

Borrowing relates to use of other languages in another language due to lack of term in that language. For instance, in English, there are some words that are borrowed from other languages as in bamboo (Chinese), Alcohol (Arabic), piano (Italia), yogurt (Turkish), boss (Dutch) and etc.

Coinage refers to the production of new word without undergoing word formation process. These words are often found in English as in Teflon, nylon, Kodak, flossy, aspirin, zipper, Kleenex, Xerox and etc.

Clipping relates to the word formation process which consists in the reduction of word to one of its part (Marchand, 1969). Clipping according to Arnold (1986) can be divided into four types- initial clipping, final clipping, medial clipping, and complex clipping. See examples below

Flu $\rightarrow$ influenza $\quad$ [initial clipping]

Fancy $\rightarrow$ fantasy [medial clipping]

Gas $\rightarrow$ gasoline [final clipping]

Cablegram $\rightarrow$ cable telegram [complex clipping]

Backformation refers to the process of creating new word by removing actual affixes as in babysit from babysitter, bartend from bartender, bulldoze from bulldozer and etc. 


\subsection{Morpho-Phonemic scope}

Katamba (1989) defines morphophonemics as the study of phonological realization of a morpheme. In the process of morphophonemics, Nurhayati (2015) says that morphophonemic process studies the phonological realization of all the allomorphs of the morphemes of a language. In addition, it analyzes the phonemic representation of morphemes in different environment. Parera (1993) states that morphophonemic process is also called morphophonemic changes because the morpheme change is based on the sounds which relates to correlation between morpheme and phonemes. Crowley (1987) divides morphological types into eight types, namely, lenition, sound addition, metathesis, fusion, unpacking, vowel breaking, and assimilation. In addition, he divides lenition into subcategories- cluster reduction, apocope, syncope, haplology, and compression.

Furthermore, Keraf (1996) mentions one more type that is called aphaeresis. It is a kind of sound deletion that happens at the beginning of the word. Sound addition has three types according to Crowley, namely, anaptixis, epenthesis, and prosthesis and one by Kerap (1996) which is called paragog. In term of vowel breaking and unpacking, Crowley (1987) takes an example from the language of Kairiru and Bislama. See below

1)

*/pale/ $\rightarrow /$ pial $\rightarrow$ home

[vowel breaking in Kairiru]

2)

/baik/

Bæg (English)

$\rightarrow$ bag

[unpacking in Bislama]

A study on morphophonemic process in Serawai language results that additional forms of phonemes are found at the end of a word which called paragog. Other processes are weakening the phoneme $/ \mathrm{k} /$ to $/ \mathrm{s} /$, reduction of consonant clusters, syncope, haplology, strengthening phonemes, phoneme breaking, metathesis, palatalization, monophthongization, neutralization, and other interphoneme changes. Thus, many morphological processes causing morphophonemic process in Serawai words borrowed from English are in the process of affixation and reduplication.

\section{Methodology}

\subsection{Research design}

This study includes in a qualitative research. It is used to describe all morphophonemic process of affixation in Ngeno- $\mathrm{Ngene}$ dialect of Sasak language. This study is conducted in the area of Ngeno-Ngene dialect in Lombok. The dialect is spoken mostly in East Lombok as in Selaparang, Pringgabaya, Wanasaba, Apit Aik, Aik Mel, Kembang Kerang and etc and in West Lombok as in Ampenan, Karang Pule, Dasan Agung, Pejeruk, Rembige, and Gunung Sari.

\subsection{Participants}

The study involves 24 native speakers from twelve villages where the dialect is spoken. Two participants are taken from every village and they are ranged from 30-50 years old.

\subsection{Data collection}

The data were collected via field linguistic method using three techniques of data collection: observation, interview, and notetaking. Observation is aimed at observing the characteristic of affixation used by speakers of Ngeno-Ngene dialect. Interview is conducted to have details about affixation from the native speakers of the dialect and note-taking is conducted along with observation and interview to write all information about affixation during observation and interview.

\subsection{Data analysis}

The data were analyzed through the following steps; 1) the data are firstly classified based on their affixes, 2) the data are then identified, 3) the data are selected based on the research question and 4) the data finally are elaborated to describe the morphophonemic process of affixation.

\section{Results and Discussion}

There are two types of phonemic changes occurred as the result of morphophonemic process of affixation in this dialect, namely, epenthesis, and weakening phoneme. The affixation that undergoes phonemic changes include prefix and simulfix.

\section{Prefix be-}

The prefix be-causes epenthesis in which lexical ' $r$ ' is inserted in between the prefix and the base. It is occurred when the base has initial vowel as in the following examples 
/a/ angen (felling) $\rightarrow$ Be $\{r\}$ angen (desire/ miss)

$/ \mathrm{i} /$ Isi (content) $\rightarrow \quad$ be $\{r\}$ isi (content)

$/ \mathrm{u} /$ utang (debt) $\rightarrow \quad$ Be $\{r\}$ utang (owe)

/e/ entiq (hold) $\rightarrow$ Be $\{r$ ) entiq (holding) /o/ oat (medicine) $\rightarrow \quad B e\{r\}$ oat

(take medicine)

The followings are examples of the words above in the sentence

Ndeqku taoq, sai jagene taoqne berangen

Not.1sg know who man.3sg place.3sg desire

"I don't know whom he has feeling with"

- Karongno berisi semen

Sack. That fill cement

"that sack is full of cement"

\section{Prefix pe-}

The prefix pe- in this dialect can cause epenthesis. This prefix can add lexical ' $n$ ' and ' $m$ '. Usually, the additional sound of ' $n$ ' occurs when the base or the word has initial letter 'j, d,and c. see below

$/ \mathrm{j} /$ jage (keep) $\rightarrow$ pe $\{\mathrm{n}\}$ jage (keeper)

/d/ dengah (hear) $\rightarrow$ pe $\{\mathrm{n}\}$ dengah (listener)

/c/ copet (pick a pocket) $\rightarrow \quad$ pe $\{\mathrm{n}\}$ copet (thief)

See the following sentences

- Ndeqne man bagus pendengahne

neg.3sg not good ear

"he/she is deaf"

- Pencopet no iye wah tebau siqpolisi beruq

Pickpocket that he already arrest.pass by police just now

"The pickpocket has been arrested by the police just now"

When the prefix pe- meets the word with initial letter $t$, the sound $t$ will be deleted and changed by the sound $n$. This is called assimilation.

Taok $(k n o w) \rightarrow$ pe $\quad$ tt------n\}aok (knowledge)

Tulong (help) $\rightarrow$ pe $\quad$ tt-----n\}ulong (assistant)

See the followings

- Mbe jaq engkah penaoqne, ampoqne macem bae ongkatne ngeraos Where fut limit know.3sg, part.3sg dare part. sound.3sg talk "how smart he is, so he dares to talk as he wishes"

When the base is initiated by lexical ' $b$ ', lexical ' $m$ ' is inserted between prefix "be-" and the base. See the following examples $/ \mathrm{b} /$ bace $($ read $) \rightarrow$ pe $\{\mathrm{m}\}$ bace (reader)

See sentence below

- Ndeqne man tao jari pembace do'e 
Neg. 3sg yet can become reader prayer

"he has not become a good prayer yet"

Assimilation also occurs when the base is initiated by the letter $s$, the letter $s$ will be changed to the nasal sound ' $n$ ' as in the following example

/s/ sapu (broom) $\rightarrow$ pe $\{$ s-----n\} apu (broom)

See the following sentence

- Mbe taoq penyapu no?

Where place broom that

"where is the broom?"

The prefix "pe-" can cause epenthesis when the base is initiated by the consonant " $g$ " and vowel sound, the velar nasal sound ' $\eta$ ' will be inserted in between the prefix and the base. See below

/g/gitaq (see) $\rightarrow$ pe $\{\eta\}$ gitaq (watcher)

/a/ adang (resist) $\rightarrow$ pe $\{\eta\}$ adang (resistent)

/i/ iring (visit/ escort) $\rightarrow$ pe $\{\eta\}$ iring (follower)

$/ \mathrm{u} /$ ulat (plait) $\rightarrow$ pe $\{\eta\}$ ulat (craftsman)

/e/ entek (pull) $\rightarrow$ pe $\{\eta\}$ entek (someone who pull)

/o/ oloq (mock) $\rightarrow$ pe $\{\eta\}$ oloq (joker)

When the base is initiated by consonant "b,c, and I", the velar nasal sound plus vowel "e" will inserted in between the prefix and the base.

bom (boom) $\rightarrow$ Pe $\quad$ nge bom (boomer)

cet (paint) $\quad \rightarrow$ Pe $\quad$ nge\} cet (someone who paint)

las (weld) $\quad \rightarrow$ Pe $\quad$ \{nge\} las (someone who weld)

See the sentence below

- Ngumbe penggitaq meq

How see $1 \mathrm{sg}$

"how is your sight?"

- Mbe taoq te mete pengecet siq bagus? Where place $1 \mathrm{pl}$ search painter which good

"where do we find a good painter?

Prefix ng-

The prefix $n g$ - will cause the assimilation when the base is initiated by the latter ' $k$ ' as in the followings

keduk (dig) $\rightarrow \quad\{k--\eta \eta$ eduk (to dig)

kereq $($ rub) $\rightarrow \quad\{k--\eta \eta$ ereq (to rub)

kaken (eat) $\rightarrow \quad\{k--\eta \eta$ aken (to eat)

kerem (soak) $\rightarrow\{k---\eta\}$ erem (to soak)

$\operatorname{kepak}($ slap/hit) $\rightarrow\{k--\eta\}$ epak (to slap) 
See the following example

- Girang ne ngepak meje lamune sili, kepale sekolah no

Often 3sh hit table when angry headmaster that

"The headmaster often hit a table when he gets angry"

- Sai ngerem popoqan ne leq ember ne?

Who soak laundy this at pail this

"Who soaks the laundry in the pail"

\section{Prefix $\boldsymbol{t}$ -}

The prefix $t$ - becomes passive marker in Sasak language and it can have vowel addition when the base is initiated by the consonant. The base with initial vowel has addition " $\mathrm{t}$ " while the consonant-initial base is added by the prefix "te". Example below shows that the base 'timpak' is initiated by consonant ' $\mathrm{t}$ ' and example 'empoh" is initiated by vowel ' $\mathrm{e}$ '.

timpak (smack down) $\rightarrow$ \{te\} timpak $\quad$ (be smacked)

empoh (call) $\rightarrow\{t\}$ empoh (be called)

- Tempoh $\mathrm{ku}$ ne siq sai jage beruq leq jurang no

Call.PASS.1sg this by whom recent at cliff that

"I have been called by anyone from the cliff"

\section{Prefix me-}

The prefix me- also causes the assimilation. In this case, the base initiated by consonant ' $p$ ' will changes into the ' $m$ ' as in the following examples

$$
\begin{array}{ll}
\text { polak (cut) } & \rightarrow \text { Me }\{\mathrm{m}\} \text { olak (to cut) } \\
\text { paling (steal) } & \rightarrow \text { Me }\{\mathrm{m}\} \text { aling (to steal) } \\
\text { pete (seek) } & \rightarrow \text { Me }\{\mathrm{m}\} \text { ete (to seek) }
\end{array}
$$

pager (hedge) $\rightarrow$ Me $\{\mathrm{m}\}$ ager (to hedge)

pasek (pin) $\rightarrow$ Me $\{m\}$ asek (to pin)

See the following examples

kejengkene memager kebon no
- Amangku fence garden that
Father.link.1sg.POSS doing
"My father is fencing the garden"

\section{Simulfix ke-an}

The simulfix ke-an in this dialect can cause epenthesis as the result of morphological process of affixation. When the base is initiated by the vowels, there will be lexical and sound addition ' $r$ '. See below

$$
\begin{array}{ll}
/ \text { a/ angkat (lift) } \rightarrow & \text { Ke }\{\text { r }\} \text { angkatan (lifted up) } \\
/ \text { i/ icaq (trample) } \rightarrow & \text { Ke }\{\text { r }\} \text { ica'an (stepped on) } \\
/ \text { / / ulang (repeat) } & \rightarrow \text { ke }\{\text { r }\} \text { ulangan (repeated) } \\
/ \text { /e/ engat (see) } \rightarrow & \text { Ke }\{\text { r }\} \text { engatan (be seen) } \\
\text { /o/ opong (lift) } \rightarrow & \text { ke }\{r\} \text { opongan (barried) }
\end{array}
$$

See the examples below

- lye kerangkatan seng ini siq lolon paoq no 
"the zinc is lifted up by the mango tree"

- Ndeqne kericaqan isiqku tain manuk no?

Neg.3sg stepped on by. 1 sg dunk hen that

"the hen dunk is stepped on by me, isn't it?"

When the simulfix ke-an is used in the base initiated by the letter ' $\mathrm{p}$ ' and ' $\mathrm{b}$ ', there will be lexical addition ' $\mathrm{m}$ ' as in the followings panas (hot) $\rightarrow$ Ke $\{\mathrm{m}\}$ panasan (to get hot)

penoq (full) $\rightarrow \mathrm{Ke}\{\mathrm{m}\}$ penoqan (too full)

besoh (full) $\rightarrow \mathrm{Ke}\{\mathrm{m}\}$ besohan (too full)

bait (take) $\rightarrow$ Ke $\{m\}$ baitan (be taken)

beseng(narrow) $\rightarrow$ Ke $\{\mathrm{m}\}$ beseng (getting narrow)

See examples below

- lye kempanasan leq dalem ampoqne sugul

$3 \mathrm{sg}$ hot at in so.3sg out

"he feels hot so he gets out"

- lye jaoq laloq taoqne, ndeqne bau kembaitan isiqku

$3 \mathrm{sg}$ far too place.3sg neg can taken by.1sg

"it is too far so it cannot be reached"

When the simulfix ke-an is added to the base which is initiated by the letter ' $t$ ' and ' $d$ ', the lexical addition ' $n$ ' as in the examples below:

dengah (listen) $\rightarrow$ Ke $\{\mathrm{n}\}$ dengahan ( be heard)

taoq (know) $\rightarrow$ Ke $\{\mathrm{n}\}$ taoqan (known)

dait (find) $\quad \rightarrow \operatorname{Ke}\{\mathrm{n}\}$ daitan (found)

tame (enter ) $\rightarrow$ Ke $\{\mathrm{n}\}$ tamean ( entered)

look at the examples below

- Ndeqne iniq kendengahan suaren radio ne

Neg.3sg can hear.PASS sound radio this

"The sound of radio cannot be heard "

\section{Conclusion}

This study aims at analyzing the morpho-phonemic process on affixation in Ngeno- $\mathrm{Ngene}$ dialect of Sasak language. The dialect has four types of affixations, namely, prefix, infix, suffix and simulfix. Prefix and simulfix are affixes that undergo morphophonemic changes when the affixation is added to the base. The morphophonemic process in prefix and simulfix result two types of phonemic changes: a) epenthesis and b) assimilation. Epenthesis occurs in the prefix 'be-' with lexical addition ' $r$ ', prefix 'pe-' with lexical addition ' $n, m$ ', prefix ' $t$ ' with lexical addition ' $e$ ', and simulfix 'ke-an' with lexical addition ' $r$,m, $n$ '. Meanwhile, assimilation happens also in the prefix 'pe-' with changes " $t \rightarrow n, k \rightarrow \eta$ ", prefix "ng-" with changes "k $\rightarrow \eta$ ", and prefix "me-" with changes " $\mathrm{p} \rightarrow \mathrm{m}$ ". These epenthesis and assimilation have the rules as explained in the discussion above. For next researcher, the scope of this study is limited to the morphophonemic process of affixation in $\mathrm{Ngeno-Ngene} \mathrm{dialect} \mathrm{so} \mathrm{other}$ researchers may explore the same aspect for other dialects of Sasak language as Sasak has six dialects to be objects of linguistic study.

Funding: This research received no external funding 


\section{References}

[1] Akmajian, A., \& Lehrer, A. (1976). NP-like quantifiers and the problem of determining the head of an NP. Linguistic analysis, 2(4), 395-413.

[2] Arnold, Irina. (1986). The English Word. Moscow

[3] Austin, Peter K. (2004). Clitic in Sasak, Eastern Indonesia. http//:hrelp.org/aboutus/staff/peter-autsin

[4] Crowley, T., \& Bowern, C. (2010). An introduction to historical linguistics. Oxford University Press.

[5] Fromkin,Victoria, et al. (1996). An Introduction to Language.Second Edition. Holt, Rinehart and Winston

[6] Hanafi, N. (2006). Morphology. Mataram. Mataram University Press

[7] Hocket, F. (1958). A Course in Modern Linguistics. McMillan Publishing Co.Inc

[8] Katamba, F. (2003) . Bantu Nominal Morphology. Routledge.

[9] Keraf, G. (1996) . Linguistik Bandingan Historis. PT Gramedia Pustaka Utama

[10] Mahyuni. (2006). Speech Styles and Cultural Consciousness in Sasak Commuinty. Mataram: Yayasan Cerdas

[11] Marchand, H. (1969). The Categories and Types of Present-Day English Word-Formation. Munchen: C.H. Beck'sche Verlagsbuchhandlung

[12] Nurhayati, D. A. W. (2015). Morphological and Morphophonemic Process of Alay Variation. LINGUA: Jurnal Bahasa, Sastra, dan Pengajarannya, 12(1), 59-70.

[13] Parera, D. (1993). Sintaksis. PT Gramedia Pustaka Utama.

[14] Ramlan, M. (1985). Tata bahasa Indonesia: penggolongan kata. Andi Offset.

[15] Sukri, M. (2015). [M<-> N] Sebagai Afiks Derivasional Dan Infleksional Dalam Bahasa Sasak Dialek Kuto-Kute. RETORIKA: Jurnal Ilmu Bahasa, 1(1), 123-136.

[16] Sutarman, S. (2017). Derivational and Inflectional Affixation in Menu-Meni Dialect of Sasak Language. Humanitatis: Journal of Language and Literature, 4(1), 121-136

[17] Sutarman, et al. (2020). On Morphological Analysis of Spatial Deixis in Məriaq-məriqu Dialect of Sasak Language. ELS Journal on Interdisciplinary Studies in Humanities, 3(3), 415-424. https://doi.org/10.34050/elsjish.v3i3.11323

[18] Yule, G. (2014). The Study of Language: the Fifth Edition. New York: Cambridge University Press 